NBER WORKING PAPER SERIES

\title{
INCREASING OUR UNDERSTANDING OF THE HEALTH-INCOME GRADIENT IN CHILDREN
}

\author{
Jason Fletcher \\ Barbara L. Wolfe \\ Working Paper 18639 \\ http://www.nber.org/papers/w18639
}

\author{
NATIONAL BUREAU OF ECONOMIC RESEARCH \\ 1050 Massachusetts Avenue \\ Cambridge, MA 02138
}

December 2012

We thank Angela Fertig, Mayu Fujii, Robert Nuscheler, participants at the IFO/CESIFO and University of Munich, Conference on Empirical Health Economics, participants at the 2010 ASHEcon Conference and participants in the econometrics for health economics seminar at the University of Wisconsin-Madison for helpful comments and suggestions. The views expressed herein are those of the authors and do not necessarily reflect the views of the National Bureau of Economic Research.

NBER working papers are circulated for discussion and comment purposes. They have not been peerreviewed or been subject to the review by the NBER Board of Directors that accompanies official NBER publications.

(C) 2012 by Jason Fletcher and Barbara L. Wolfe. All rights reserved. Short sections of text, not to exceed two paragraphs, may be quoted without explicit permission provided that full credit, including $\odot$ notice, is given to the source. 
Increasing Our Understanding of the Health-Income Gradient in Children

Jason Fletcher and Barbara L. Wolfe

NBER Working Paper No. 18639

December 2012

JEL No. I1,I12,I14,I3

\begin{abstract}
$\underline{\text { ABSTRACT }}$
There have been numerous attempts to both document the income-health gradient in children and to understand the nature of the tie. In this paper we review and summarize existing studies and then use a unique school based panel data set from the US to attempt to further our understanding of the relationship. The long duration ( 5 observations, 9 years) allows us to add to the understanding of the pattern of the tie, through our ability to test for changes in health status and multiple measures of income, and the school-based nature of the data allow us to add community SES to the model. Increasing understanding of the income-health gradient may allow more effective targeting of interventions to decrease the gradient and hence decrease health disparities among children.
\end{abstract}

Jason Fletcher

Yale School of Public Health

Department of Health Policy and Management

60 College Street, \#303

New Haven, CT 06520

and NBER

jason.fletcher@yale.edu

Barbara L. Wolfe

1225 Observatory Dr

University of Wisconsin

Madison, WI 53706

and NBER

BWolfe@wisc.edu 


\section{INTRODUCTION AND LITERATURE REVIEW}

The observation that there is a relationship between income and health has a long history but research on the nature of the relationship and its causes has exploded in recent years. Part of the interest may be tied to trying to understand the increasing inequality in income and wealth found in many developed countries; but part of it is likely tied to the large disparities in health that seem to exist and perhaps increase even in the face of more and more effective health care. These disparities seem closely tied to disparities in income and more generally socio-economic status (SES). The relationship has been difficult to study because the causal pattern is far from clear, in part due to important and unresolved empirical issues in most investigations of potential reverse causality (whether poor health leads to low income (and/or vice versa)) as well as potential "third factors" that simultaneously affect both health and income. And there are derivative questions for policy such as how to design policies to reduce disparities in health.

Recent efforts to understand the so-called income gradient have focused on two strategies: study children, for whom the likely path is from family income to health, and use natural experiments. We follow the first strategy and focus on children but we note here that the study of natural experiments has provided consistent evidence that an increase in income, or in some cases an increase in community resources, is tied to improvements in health ${ }^{1}$. These studies include unexpected changes in pensions for elderly black and Coloured in South Africa (Case, 2004), an experimental program providing conditional cash transfers in Mexico (the Progresa or Opportunidades program (see Ferdinand, Gertler and Neufield, 2008)), and the introduction of casinos by American Indian tribes once legalization was established in 1988 (see Costello, 2003 and Wolfe, et al 2012).

Children are studied because, for most children in developed countries, family income does not depend on their own health. This largely eliminates one possible causal path. However,

\footnotetext{
${ }^{1}$ A possible exception is work by Ruhm on the influence of unemployment on health; but the test in that research is not only on income but changes in the allocation of time and in stress.
} 
there is some evidence that children's health can affect family income through effects on (usually maternal) labor supply (see Gould 2004).

There are consistent and well established differences in children's health based on family income along a variety of measures and across countries (see Appendix Table 1). The sources of these differences are not yet fully elucidated. Indeed, the functional form of this relationship is also in question. Potential threshold effects of low income (e.g. extreme deprivation) may be an important factor driving poor health through inadequate nutrition, lack of access to and utilization of quality health care. Deprived geographic areas may also expose individuals to a variety of physical hazards and high stress levels. If so, then we expect to see a much flatter gradient in countries with more generous support systems either in terms of income and/or access to health care.

An alternative to the threshold model of the effects of income on health is that ever more income continues to lead to better health, as those with more income can buy more nutritious food, live in a safer environment, belong to health clubs, obtain high quality medical care. That is, more income continuously allows one to have better health. And if so, a corollary question is whether there a declining marginal gain in health from increasing income at high levels of income. This last question is particularly relevant for transfer programs and, if true, suggests that among two communities with equal average income, the one with more equality in income will have better average health than a community with more inequality in income.

A new variant of the question and one we pursue here is to ask if family income leads to significant changes in children's health as they age. That is, does the health of children in the family improve (decline) over time depending on family income? If so this would provide additional and perhaps more convincing evidence that income influences health (rather than other family characteristics such as parental education.) And, related to this, among children in poor/very good health at Kindergarten, we examine whether the links between income and health are similar as they age through school. 
In the rest of the paper we focus on children in order to better understand the gradient.

We first review the existing literature beginning with the Case, Lubotsky, and Paxson paper of 2002 before turning to our own work. In doing so we point out some of the limitations and lay out the contribution of our work that follows. The model underlying the work is quite standard and is found in Appendix 2. Briefly, the focus of the conceptual framework is to use a child health production function, where measured child health at a point in time $t$ is determined by an initial stock of health at birth as well as subsequent parental and other inputs between birth and time t (during elementary school).

The literature using children as the subjects often use general health as the outcome of interest and focus on log family income as the primary variable of interest ${ }^{2}$. A set of controls including race/ethnicity dummy variables, parental background, child's sex and sometimes measures of the child's initial health (birth weight) or mother's mental health and education are also included. The model is estimated separately by age of the subjects. Once this model is specified there remain several core issues: (1) even with children, family income may be endogenous (in the case of a child with severe disability, parents may alter their work behavior and hence income) (2) How to measure health? The most commonly used measure is general health in which an individual or responsible adult responds whether their children's health is excellent, very good, good, fair or poor (3) How to best measure income? The possibilities include current or annual, permanent, neighborhood, or for some purposes, whether the family is poor or near poor.

The first paper to explore the question of the time path of the income gradient among children is Case, Lubotsky and Paxson (2002) (CLP). Using primarily cross sectional data from the National Health Interview Survey [NHIS] for years 1986 to 1995 for children 0-17 they

\footnotetext{
${ }^{2}$ A small but growing set of papers have extended the analysis of child health to include other health indicators, such as body mass index, asthma, risky behaviors, and other measures of child development (e.g. Berger et al. 2005, Blau 1999, Currie et al. 2007, Dooley and Stewart 2008, Violato et al 2009, 2011, Reinhold and Jurgen 2011)
} 
explore the time path using four age categories $(0-3 ; 4-8 ; 9-12$ and 13-17). Using the general health measure and ordered probit regression they find clear evidence of an income-health gradient at all ages and a steepening gradient with age. They explore this pattern as well using a panel data set (Panel Study of Income Dynamics or PSID) and find the same pattern. Through using the panel data, they explore a limited set of alternative income measures that all show the same steepening influence of income as children age. We note here that while the PSID has numerous measures over family income over time, there are few measures of children's health collected.

This paper set off a chain of other studies — some use data from other countries, which have universal health insurance (e.g. U.K., Germany and Canada), while others use alternative data sets for the U.S. Many of these are included in Table 1 below, which documents the question asked, the data set used, methods, findings and a summary-sentence on implications. For example, Currie and Stabile (2003) use data from Canada to ask if the same steepening pattern exists for children under universal coverage. In addition to replicating the CLP study they also attempt to understand if the "cause" for this pattern is that low income children are less able to recover from a health shock than higher income children or that low income children are subject to more health shocks. Health shocks are defined by a set of chronic conditions. Their results suggest that, at least in Canada, low income children recover as well as higher income children from a health shock but have more of them.

In Table 2 we compare results across several studies and countries. We bring together the coefficients from ordered probit runs using log income. Each of these studies uses the same five response general health outcome variable, excellent $=1$ to poor $=5 .^{3}$ The right hand side control

\footnotetext{
${ }^{3}$ In some cases these categories have been collapsed to two or three categories. Numerous studies have explored the reliability of self or parent reported general health. The focus is on their ability to predict future morbidity and mortality. Maarten Lindeboom and Eddy van Doorslaer 2004 in Journal of Health Economics 23(6): 1083-1099 reported on using data on Canadian adults and found homogenous reporting of health status for language, income and education. Marja Jylha_2009 in Social Science \& Medicine 69(3): 307-316 states this more strongly: "In population studies, self-rated health is probably the most feasible,
} 
variables generally include child's sex, race/ethnicity, mother's age, mother's education and parent's marital status. ${ }^{4}$ In each case we see a substantial increase in the coefficient going from the youngest age group, $0-3$ to the next age group, $4-8$. However moving to the third age group, 9-12, the results are more mixed with half of the studies showing no steepening between the second and third group. Finally moving to the oldest group, 13+, suggests an increase or steepening, with the study of the U.K. as the only exception (the fifth study of Australian children only has the two youngest ages included.) German data suggest a slightly different pattern where the coefficients are largest for the oldest age group but flat for the three younger groups. Thus all six of the included studies provide evidence of a general steepening of the income gradient as children age with strong evidence for young children but more mixed evidence for the 9-12 year olds.

All of these studies are either done with cross sectional data or short panels (2 observations per child). This limits their ability to study whether it is current income or permanent income that appears more closely tied to a child's health and whether health changes in response to permanent low or high income. ${ }^{5}$ The one study (Condliffe and Link 2008) that uses the PSID has two observations on child health but does not make use of the fuller data on family income. Murasko (2008) does explore a few dimensions of income including hot deck imputations for missing income, the use of income from one year rather than a 2 year average and the use of wage income in place of family income. He finds that the two year average income (and family income vs. wage income) shows a stronger tie to child health. But his use of year two income, measured subsequent to the initial observation of child health casts some doubt on the

most inclusive and most informative measure of health status. In a given cultural environment, it is a powerful predictor of future health and use of health services."

${ }^{4}$ We exclude studies that use a more limited set of covariates such as Chen et al 2006 which uses only child age, sex and race.)

${ }^{5}$ Permanent income is generally defined in these short panels as the average income over two years and is then used to explore the health income gradient for all measures of children's health regardless of timing. 
reliability of his comparison of permanent versus current income. The approach used in both Khanama et al and Murasko is to use the earliest or prior health status to capture the influence of income on children prior to the age under study. Thus they suggest that including prior health (by an indicator of poor/fair health for example) captures the influence of income on health up until the most recent period of time. Under this perspective, estimates of the tie between income and health in the current period capture only the marginal influence of income on health. This approach reduces the coefficient on income but still retains the overall pattern of results. We explore this pattern for the U.S.

Thus the existing literature confirms that children's health is tied to income with some steepening as child age, particularly in earlier childhood, and, that universal health care is not sufficient to significantly reduce, let alone eliminate, this income gradient. But there are several remaining problems with the analysis that we address in our analysis below. Our primary contribution is to our ability to test how income influences repeated measures of health of the same individual over time. That is, while others such as Case et al have used repeated measures of income, and so can compare prior income measures, they have not been able to measure the tie between alternative measures and repeated measures of health. Second, we have a measure of neighborhood income, so we can test both the tie between community income and child health and whether inclusion of community income reduces the influence of family income. The first of these - the tie between community income and health is potentially important when considering possible policy interventions and is built upon the natural experiment literature which suggests a greater influence of increases in health if community (and individual) income increases rather than simply individual family income (Wolfe et al 2012 )

Compared to our analysis, each of the studies we discussed above has one or more of the following limitations: (1) use of cross-sectional data or short panel data rather than long duration panel data, and especially single time observations of health (2) reliance on noisy income measures and (3) inability to control for environmental confounding influences, such as 
neighborhood SES and crime, which can affect both family income and child health status. In this study we overcome these limitations by using a long panel data set with repeated measures of each child's health and a (repeated) measure of neighborhood income. In particular, we employ the Early Childhood Longitudinal Study-Kindergarten Cohort data, which follows children from the US over 9 years between Kindergarten entry and $8^{\text {th }}$ grade and includes five observations of health and family income per child. The ECLS-K also uses a school-based sampling scheme, which allows the use of average income of the school as well as the average health of children in the school; it also includes an appropriate measure of the child's health endowment (birth weight). The multiple observations per child allow us to construct a far better measure of permanent income, and to compare it with a variety of alternative measures. Finally the panel nature of the data allows us to explore how family income influences changes (declines) in health. We turn to our research below.

\section{DATA}

In the research reported below we use the Early Childhood Longitudinal StudyKindergarten Cohort data [ECLS-K]. These data were collected beginning in 1998-99 and trace US children from kindergarten through grade 8 . The correspondence between grade and child's age is: Kindergarten $6.28(.88) ; 1^{\text {st }}$ grade $7.24(.87), 3^{\text {rd }}$ grade $9.25(.87), 5^{\text {th }}$ grade $11.87(0.80)$ and $8^{\text {th }}$ grade, $14.45(.49)$ thus the sample goes from about age 6 to age 15 . There are 6431 observations. Table 3 shows basic descriptive information of our sample at kindergarten and $8^{\text {th }}$ grade. Across all five observations, the proportion of children in the sample with health that is less than or equal to good health varies from .15 to .20 over the five observations with a standard deviation [S.D] of .36-.40. Current income in $\$ 10,000$ s varies from $\$ 5.1$ to $\$ 7.0$ with a S.D. that varies from 4.6 to 5.2. Permanent income, measured as the average income over the survey waves, (in $10,000 \mathrm{~s}$ ) varies from $\$ 5.1$ to $\$ 6.1$ with a S.D. of 4.4 to 5.1. These rather narrow and 
consistently sized S.D. suggest that any pattern that emerges should not be due to changing S.D.

in income or health.

\section{RESULTS}

We begin by replicating the CLP model using the longer panel of the ECLS-K data.

These full results are shown in Appendix Table 2. The equations we estimate are:

$$
H_{i t}=\alpha+\beta_{1} \log \left(Y_{i t}\right)+\beta_{2} X_{i t}+\varepsilon_{i t}
$$

where the health measure is the five response general health in which $1=$ poor and $5=$ excellent health in the specified grade, which are estimated separately by grade-level using an ordered probit specification. In addition to current log income (which is based on 26 categories with a top category of greater than $\$ 200,000^{6}$ ) the additional control variables are male, age in years, dummy variables for race (Black, Hispanic and Other race with White, non-Hispanic as the omitted category), Mother's age, mother's marital status, mother's education, and a dummy variable indicating missing parent information ${ }^{7}$. We modify the specification slightly to include birth weight, a measure of initial health that we believe belongs in the model ${ }^{9}$. We also estimate the model for subsets of students, such as those with poor/fair health and those with good or better health at baseline and we explore whether income is protective of declines in health as children age through school.

\footnotetext{
${ }^{6}$ The mid-point of each category is used in the analysis; for the highest category we use $1.5 *$ the highest cutoff. In two data waves, continuous income measures are available; we use continuous when available.

${ }^{7}$ Mother's age and marital status are updated each wave, but mother's education at baseline is used throughout the analysis.

${ }^{8}$ Consistent with most of the literature we use family income without adjusting for family size. Below we test the importance of this by adjusting family income using the equivalence scale suggested by the National Academy Committee's recommendations for measuring poverty. We also control for family size in a robustness check.

${ }^{9}$ See Conley et al (2003) for an overview of the importance of birth weight on health and socioeconomic outcomes. We estimated all of our models without the birth weight variable as well; in no case did these results differ substantially in terms of the underlying income health gradient (results available from the authors by request).
} 
The initial results show the expected tie between more income and better health from $\mathrm{K}$ to $5^{\text {th }}$ grade but a flat or decreasing tie by the $8^{\text {th }} \operatorname{grade}^{10}$. These results then are consistent with the literature reviewed above and suggest that the use of grades in place of age maintains the incomehealth gradient ${ }^{11}$. We next explore the income health gradient making use of the richness of the ECLS-K.

Permanent income: As in other avenues of economic research focusing on the long term role of income, it is important to have an accurate measure of permanent income. Our first definition of permanent income is one that uses only those measures of income observed up to the present at each grade level; by grade 8 , all five measures of income are included. We run the same basic ordered probit but substitute our measure of permanent income for current income. Figure 1 indicates that the gradient is steeper with the use of permanent income and shows a pattern of continual steepening, with a far greater slope between $5^{\text {th }}$ and $8^{\text {th }}$ grade with a difference that reaches .07 or nearly 30 percent higher by $8^{\text {th }}$ grade. The influence of income appears to be more than 100 percent greater by grade 8 compared to kindergarten. All of the coefficients on income are statistically significant at the one percent level. ${ }^{12}$

Next, with our rich data we compare our several alternative definitions of permanent income, including that used in other studies; that is we compare permanent income which only uses income already observed at the time the health data is gathered with a definition that uses all income measures for each family, first a two year rolling average and then a three year rolling

${ }^{10}$ Pooling the data, we can test whether the coefficient on income is statistically different across data waves in comparison to the effect in Kindergarten. We find that the effect, relative to baseline, becomes statistically distinguishable in the $5^{\text {th }}$ grade and $8^{\text {th }}$ grade waves in models that control for demographic variables. The $5^{\text {th }}$ grade and $3^{\text {rd }}$ grade effects are different at $\mathrm{p}<0.12$ level.

${ }^{11}$ To explicitly review the comparability of using grade based data for ages, we compared our results using grades to the Khanama et al study based on Australian data which also used grade levels. In results available upon request, we found a high degree of consistency, including a steepening gradient between Kindergarten and $1^{\text {st }}$ grade. These results provide evidence of the consistency of using grades for age in studies of the income-health gradient of children.

${ }^{12} \mathrm{By}$ definition the gradient begins at the identical spot for kindergarten. 
average $^{13}$ from Kindergarten to grade 8 and tie that measure to health at each grade (see Table 4). The use of these measures of permanent income suggests a greater tie between income and health at early grades than our other measures but a flatter overall tie. The permanent income measure that uses all years of observed income is the flattest of these estimates of the gradient with a much greater coefficient at kindergarten and then a gradually increasing set of coefficients except for a slightly smaller coefficient for $5^{\text {th }}$ grade compared to $3^{\text {rd }}$ grade. Again, the coefficient for $8^{\text {th }}$ grade is the largest of the set (and by definition equal to that in our first estimate of permanent income). Compared to the coefficients on current income and our first measure of permanent income, the pre-post measure does not seem to accurately represent the income health gradient on children in the earlier years, when the measure is most likely to be an error of the families' income at those points in time. Overall our interpretation of this three way comparison is that the pre-post measure of permanent income overstates the initial extent of the income gradient and understates the steepening. It raises a question of the interpretation by Case et al. (2002) that long term average income determines health investments and health status at different ages. Our findings using both repeated measures of income and health suggest that the exact pattern of the steepening of the gradient as a child ages is sensitive to the measure of income employed. ${ }^{14}$

Finally we ask whether the use of an equivalence scale modifies the results. In most economic analysis, the use of income adjusted for family size is preferred. In this way, rather than

${ }^{13}$ These rolling measures allow three waves of income measures to be included in each calculation, based on the closes measurements in time. For example, Wave 1 includes income from Wave 1,2 , and 3, Wave 2 also includes measures from Wave 1, 2, and 3, while Wave 4 includes measures from Waves 3,4 , and 5 .

${ }^{14}$ In another test of the sensitivity of the gradient to the definition of income, we explore a 3 year and then a 2 year rolling average which only includes income up to the grade level observed. For first grade this is the same as that reported above but for later grades it is not. For example, for fifth grade we use grades 1,3 and 5 for the 3 year rolling average here but income from grades 3,5 , and 8 in the measure reported above. For both of these specifications, the gradient is continually increasing but the gradient is flatter than our preferred use of all measures of income up to the grade observed. Again, the timing of measures does seem to matter to our measurement of the tie between family income and child health (results available from authors.) 
assuming that the full family income is available for all family members, an adjustment is made so that larger families have less income available for each household member than the same total family income for a smaller unit. The problem however, is which equivalent scale to use. The federal poverty line has one scale while the World Bank and other research organizations use quite different scales. Below we report on results using two different equivalence scales: the first a simple one that uses the square root of family size (Smeeding et al 1993) and the other a three parameter scale that was recommended by a volume from The National Academy on measuring poverty ${ }^{15}$

Appendix Table 3 shows our results comparing our measure of permanent income with these two alternative equivalence scales. The results are quite similar using the two different scales. Compared to the unadjusted estimates the adjusted versions suggest a somewhat flatter gradient although in all cases the gradient is increasing over the 9 year period. And once again, all coefficients on income are statistically significant at the 1 percent level.

Timing of Income and Health Transitions: A unique feature of our study is our ability to explore several aspects of the link between family income and health using the long duration panel data. Here we pursue several aspects of the income gradient of health. We first examine how income at a point in time (i.e. different baseline periods) is related to child health at the various ages captured in our sample. We then utilize the relatively unique information contained in multiple reports of child health for each child to examine the likelihood of health transitions linked to family income. Table 5 presents results that link family income measured in each of the first four waves of data with current and future measures of child health. Row 1 provides baseline results from prior tables. Row 2 suggests that income measured at school entry is

\footnotetext{
${ }^{15}$ More specifically this scale has the following form: $\left(1+\alpha^{*}(\mathrm{~A}-1)+\kappa \mathrm{K}\right)^{\theta}$ where A are adults, $\mathrm{K}$ are children, an additional adult increases needs by $\alpha$ percent of the needs of a single individual, a child increases needs in the family by $\kappa$ percent of the needs of a single individual, and the scale elasticity is constant and is equal to $\theta$. We use .7 for $\kappa$ and $\theta$.
} 
associated with good child health throughout elementary and middle school but that this effect is constant rather than increasing. Similarly, Rows 3-5 each suggest that income measured at later child ages increases in its effect on child health (consistent with Case et al. 2002 and others) but that the effect of income at each "baseline" is then relatively constant in its effect as children age. This is suggestive that income is related to child health both due to current expenditures/resources as well as due to the serial correlation and accumulation of these advantages as children age.

Related to our ability to test timing, we next examine the effects of family income in predicting negative transitions in child health (see Table 6a). These results begin with a sample of children who are in excellent/very good health at baseline and follow them over time, noting when their health declines. We then examine whether family income is linked to the likelihood that children's health declines as they transition through elementary and middle school ages. Indeed, we find that income reduces the likelihood of health declines in $1^{\text {st }}$ Grade by nearly 4 percentage points, which grows to 6.6 percentage points by eighth grade. ${ }^{16}$ This pattern is fully consistent with the income gradient results we report above and suggest that higher family income protects a child's health over the childhood years. This is an important addition to understanding the income-health gradient.

Finally in Table $6 \mathrm{~b}$ we explore an alternative way of trying to understand ways in which income influences child health: we examine whether the health of most children remains the same as they age (being generally good or better), but as health conditions develop over time, some children become manifestly sicker. These could be the children of poorer parents. To examine this question, we divide the sample into two subsamples: children with baseline very good or excellent health and children with baseline poor, fair or good health. What we find is that children who had very good or better health in kindergarten appear to experience the same pattern

\footnotetext{
${ }^{16}$ We examined these effects in two ways. In Table $5 b$, the outcome variable is an indicator of whether the child's health in the current grade is lower than at the previous grade. In unreported results, we find similar effects if instead the outcome variable is an indicator of whether the child's health in the current grade is lower than at school entry.
} 
as the overall sample: an increasing influence of family income over time as the children get older. In contrast, those children who reported poor or fair health in kindergarten do not appear to be influenced by income through the third grade and only then begin to experience a similar income gradient as other children. Thus in contrast to the idea that the income gradient is based primarily on children whose health was poor early in life, we find a stronger pattern for those who reach age 4-5 with very good or better health.

School Level Measures: Another unique aspect of the ECLS-K data is the school based design. This allows us to take into account the average SES of the neighborhood in which these children live. That is, we view each school as being similar to a relatively homogeneous community in terms of SES. We base this perspective on the neighborhood feeder pattern of a large majority of schools in the U.S. ${ }^{17}$ To test the influence of neighborhood income on the health gradient, we aggregate the individual level income measures to the school level (leaving out the focal individual). Our interest in this stems at least in part from results using American Indian tribes where running casinos both increased average income and improved health suggesting an important role for community SES (Wolfe et al, 2012). Table 7 presents these results. We do this first using the mean and then the median of school income defined as noted above. Next we examine whether there appears to be an additional influence of average school income on the health of students; in this case we have both family permanent income and school income (mean and median in separate estimates). The results including only school average income suggest positive influence of school income on health with weaker effects for $8^{\text {th }}$ grade. This could be due to the larger school and less precise measure of income in $8^{\text {th }}$ grade or that neighborhood income matters less for adolescents. For both measures of school income, the largest coefficient is for $1^{\text {st }}$ grade. Thus these results suggest a positive tie between neighborhood or school income and health but not an increasing gradient over time. The estimates with both

\footnotetext{
${ }^{17}$ For example Jorge Martinez-Vazquez, Mark Rider and Mary Beth Walker 1997 found in their study of the heterogeneity of geographic areas by race that the number of school districts tend to increase when racial heterogeneity of a state population increases.
} 
family income and school average income suggest that school income is an additional factor influencing health of young children (kindergarten and $1^{\text {st }}$ grade). Thus at least for younger school aged children living in a higher SES area does appear tied to better health., That is, in kindergarten and first grade, attending school with wealthier classmates seems to be tied to reporting better health and that this does not differ according to own family income. The influence of family permanent income is little changed with the addition of school average income, especially when mean school income is included. ${ }^{18}$

As an additional examination using the school-based nature of the dataset, we also estimated results with school (classmate)-level measures of health included. Table 8 presents these results. Although the health of classmates is statistically linked with own-health, we both find that this relationship declines as children age and also find little detectable change in the effect of family income on child health, results fully consistent with those on school based income. Thus family income matters for child health over and above the "purchase" of higher income or healthier peers in a child's school.

\section{Magnitude of Effects}

Thus we conclude that we find strong evidence of an important income gradient of health that increases as children age (are in older grades). To get a sense of the magnitude of the likely influence, we calculated marginal effects for the ordered probit specifications for the entire sample and the two subsets based on initial health using current-period measures of family income. These results are presented in Table 9. For the overall sample, the marginal effect of increasing income is found to predict a 5.7 percentage point increase in the likelihood of reporting excellent health in Kindergarten, which increases to a 12.1 percent increase by $8^{\text {th }}$ grade. In all these calculations, the income variables are statistically significant at the $1 \%$ level, and these marginal effects are calculated at the mean of all variables in the model. In Table 9 Panel B we

\footnotetext{
${ }^{18}$ We also estimated specifications using a school fixed effects model over children in all schools in the sample. The school fixed effects results suggest a general pattern of an increasing income gradient but with a decreasing slope between grades 5 and 8 . Results are available from the authors.
} 
first show marginal effects for those with poor, fair or good health at our first measure, during Kindergarten (following Table 6b). Since the coefficients underlying these estimates were not significant for Kindergarten, first or $3^{\text {rd }}$ grade, we pay no attention to the effects for those grades. Turning to the marginal effects for those who started school with very good or excellent health, we see the following pattern, which is similar to the overall pattern in panel a; the marginal effect of increasing income is found to predict a 4.3 percentage point increase in the likelihood of reporting excellent health in Kindergarten, which increases to a 8.5 percent increase by $8^{\text {th }}$ grade. This is not as dramatic an increase as that for the overall population together, especially by $8^{\text {th }}$ grade. The explanation is that the groups in fair, poor, or good health experience a significant improvement in their health in grades 5 and 8 , so that the full sample experiences the large and significant 12.1 percentage point increase in grade 8 . In all these calculations, the income variables are statistically significant at the 5\% level and these marginal effects are calculated at the mean of all variables in the model. These results then confirm a strong influence of family income on health along with an increasing gradient for all children in the ECLS. Those in very good or excellent health experience the income gradient over all grades while those in poor, fair

or good health (the less healthy kindergarten children) experience the income gradient beginning in about fifth grade.

\section{CONCLUSION}

After reviewing many aspects of the existing literature we find robust evidence of a strong and generally steepening income gradient of health regardless of the exact measure of family income that is included in the analysis. A primary contribution of this paper is our ability to explore multiple measures of health for the same child, allowing novel investigations on the impact of family income on changes in children's health as they age through elementary school.

Second, since we have such a long period of time over which we observe each child, we construct a variety of measures of long term or permanent income over time and show the robustness of our 
principal findings. Third, we add to the current exploration that focuses only on family income, by including community SES as captured by the SES of the children who attend the same school as the "observation" child. That is, by using school average income, we include a measure for otherwise unobserved community heterogeneity and implicitly include a test for the extent to which the child's family income matters, once we take community income into account.

Our results using panel data of children from age 6 to 15 provides quite clear evidence of a tie between family income and child health that steepens at least from ages 6 to about 12 . We provide evidence that the use of permanent income, including only income measured prior to the period when a child's health is measured, shows a strong increasing income gradient of health, and we provide evidence that, at least for kindergarteners and first graders, community (school) income may itself influence a child's health. The fact that family income is robust to the inclusion of school income suggests there is little bias in excluding neighborhood income in other studies, at least for the U.S. Finally, we show novel evidence that family income is related both the levels and the changes in children's health as they age.

Of course there are caveats in using the ECLS-K data. Chief among these is that not all children are present at each wave. In the analysis presented above we chose to present the results using the maximum sample possible at each grade. But this opens up the possibility that temporary attrition may influence the results. To partly answer this, we conducted an analysis using a balanced sample. These results, presented in Appendix Table 4 suggests that while there are some differences in using the balanced sample, the overall pattern remains and so again the evidence on the income gradient appears robust to numerous modifications. 


\section{References}

Berger LM, Paxson C, Waldfogel J. 2005. Income and child development. Center for Research on Child Wellbeing. Working Paper ] 05-16-FF, Princeton University.

Blau DM. 1999. The effect of income on child development. Review of Economics and Statistics 81: 261-276.

Case, Anne, Darren Lubotsky, and Christina Paxson. 2002. "Economic Status and Health in Childhood: The Origins of Gradient." American Economic Review 92(5): 1308-1334

Case, Anne. 2004. "Does Money Protect Health Status? Evidence from South African Pensions." In Perspectives on the Economics of Aging, edited by D. Wise. Chicago: University of Chicago Press.

Case, Anne, Diana Lee, and Christina Paxson. 2007. "The Income Gradient in Children's Health: A Comment On Currie, Shields And Wheatley Price.” NBER Working Paper No. 13495. Cambridge, MA: National Bureau of Economic Research.

Chen, Edith, Andrew Martin, and Karen Matthews 2006. "Socioeconomic Status and health: Do gradients differ within childhood and adolescence?" Social Science and Medicine. 629: 2161-2170.

Condliffe, Simon, and Charles R. Link. 2008. "The Relationship between Economic Status and Child Health: Evidence from the United States." American Economic Review 98(5): $1605-1618$.

Conley, Dalton, Kate W. Strully, Neil G. Bennett, The Starting Gate: Birth Weight and Life Chances (Berkeley, University of California Press, 2003).

Costello, E. Jane, Scott N. Compton, Gordon Keeler, and Adrian Angold. 2003. "Relationships between Poverty and Psychopathology: A Natural Experiment." Journal of the American Medical Association, 290(15): 2023-2028.

Currie, Janet, and Mark Stabile. 2003. "Socioeconomic Status and Child Health: Why Is the Relationship Stronger for Older Children?" American Economic Review 93(5): 18131823.

Currie A, Shields MA, Wheatley Price S. 2007. The child health/family income gradient: evidence from England. Journal of Health Economics 26: 213-232.

Dooley M, Stewart J. 2007. Family income, parenting styles and child behavioural-emotional outcomes. Health Economics 16: 145-162.

Fernand, Lia CH, Paul J. Gertler, Lynnette M. Neufeld. 2008. "Role of Cash in Conditional Cash Transfer Programmes for Child Health, Growth, and Development: An Analysis of Mexico’s Oportunidades." Lancet 371(9616): 828-837

Gould, Elise. (2004). “Decomposing the Effects of Children's Health on Mother's Labor Supply: Is It Time or Money?" Health Economics, 13(6):525-541 
Grossman, Michael. 1972. "On the Concept of Health Capital and the Demand for Health." Journal of Political Economy 80(2): 223-255.

Jylha, Marja. 2009. "What Is Self-Rated Health and Why Does It Predict Mortality? Towards A Unified Conceptual Model.” Social Science \& Medicine 69(3): 307-316.

Khanama, Rasheda, Hong Son Nghiemb, and Luke B. Connelly. 2009. "Child Health and the Income Gradient: Evidence from Australia.” Journal of Health Economics 28(4): 805817.

Lindeboom, Maarten, and Eddy van Doorslaer. 2004. "Cut-Point Shift and Index Shift in SelfReported Health.” Journal of Health Economics 23(6): 1083-1099.

Martinez-Vazquez, Jorge, Mark Rider, and Mary Beth Walker. 1997. "Race and the Structure of School Districts in the United States." Journal of Urban Economics 41(2): 281-300.

Murasko, Jason E. 2008. "An Evaluation of the Age-Profile in the Relationship between Household Income and the Health of Children in the United States." Journal of Health Economics 27(6): 1489-1502.

Propper, Carol, John Rigg, and Simon Burgess. (2007). "Child Health: Evidence on the Roles of Family Income and Maternal Mental Health from A UK Birth Cohort." Health Economics, 16: 1245-1269

Reinhold, Steffen and Hendrik Jurges. 2011. "Parental Income and Child Health in Germany." Health Economics. 21:5562-579.

Smeeding, T. M., P. Saunders, J. Coder, S. Jenkins, J. Fritzell, A. J. M. Hagenaars, R. Hauser, and M. Wolfson. 1993. "Poverty, Inequality, and Family Living Standards Impacts Across Seven Nations: The Effect of Noncash Subsidies for Health, Education, and Housing". Review of Income and Wealth 39, 229-256.

Violato M, Petrou S, Gray R. 2009.The relationship between household income and childhood respiratory health in the United Kingdom. Social Science \& Medicine 69: 955-963.

Violato M, Petrou S, Gray R, Redshaw M. 2011. Family income and child cognitive and behavioural development in the United Kingdom: does money matter? Health Economics. 20: 1201-1225.

Wolfe, Barbara, Jessica Jakubowski, Robert Haveman, and Marissa Courey. 2012. “““ The Income and Health Effects of Tribal Casino Gaming on American Indians”. Demography, 49:2 May. 499-524. 
Table 1: Table of Studies of Children

\begin{tabular}{|c|c|c|c|c|c|c|c|c|}
\hline Paper & $\begin{array}{l}\text { Case, A. Lubotsky, D., } \\
\text { and Paxson, C., } 2002\end{array}$ & $\begin{array}{l}\text { Currie, J. and Stabile, } \\
\text { M., } 2003\end{array}$ & $\begin{array}{l}\text { Condliffe, S. and Link, } \\
\text { C. R., } 2008\end{array}$ & $\begin{array}{l}\text { Currie, A. Shields, M. } \\
\text { A., and Price, E. } 2007\end{array}$ & $\begin{array}{l}\text { Currie, J. Decker, S., } \\
\text { and Lin, W., } 2008\end{array}$ & Murasko, J., 2008 & $\begin{array}{l}\text { Khanama, R., } \\
\text { Nghiemb, H. S., and } \\
\text { Connelly, L., } 2009\end{array}$ & $\begin{array}{l}\text { Reinhold and Jurges, } \\
2011\end{array}$ \\
\hline Motivation & $\begin{array}{l}\text { Focus on children; } \\
\text { sources of the gradient }\end{array}$ & $\begin{array}{l}\text { Canada; Focus on } \\
\text { recovery and quantity } \\
\text { of shocks }\end{array}$ & $\begin{array}{l}\text { US; Focus on recovery } \\
\text { and quantity of shocks }\end{array}$ & $\begin{array}{l}\text { England; Compare } \\
\text { with US }\end{array}$ & $\begin{array}{l}\text { Focus on public health } \\
\text { insurance expansions }\end{array}$ & $\begin{array}{l}\text { Health; cumulative vs. } \\
\text { current income; panel }\end{array}$ & $\begin{array}{l}\text { Australia; panel; } \\
\text { explain gradient }\end{array}$ & Gernamy \\
\hline Data & $\begin{array}{l}\text { Maternal reported } \\
\text { general health status of } \\
\text { children }(0-17)\end{array}$ & & $\begin{array}{l}\text { US MEPS and PSID, } \\
\text { 1996-2002 }\end{array}$ & $\operatorname{HSE}(2-15)$ & US NHIS 1986-2005 & US MEPS 1996-2005 & LSAC 2 Cohorts & $\begin{array}{l}\text { KiGGS 2003-2006 } \\
\text { parental and medical } \\
\text { interviews. Use general } \\
\text { health and biomarkers. }\end{array}$ \\
\hline Method & $\begin{array}{l}\text { Ordered probit } \\
\text { regression }\end{array}$ & $\begin{array}{l}\text { Ordered probit } \\
\text { regression and linear } \\
\text { probability regression }\end{array}$ & $\begin{array}{l}\text { Ordered probit } \\
\text { regression and linear } \\
\text { probability regression }\end{array}$ & $\begin{array}{l}\text { Ordered probit } \\
\text { regression and linear } \\
\text { probability regression }\end{array}$ & $\begin{array}{l}\text { Index of generosity of } \\
\text { the state's public } \\
\text { health insurance } \\
\text { programs as IV for } \\
\text { individual } \\
\text { Medicaid/SCHIP } \\
\text { eligibility and conduct } \\
\text { 2SLS }\end{array}$ & Ordered probit & $\begin{array}{l}\text { Binary and ordered } \\
\text { Probit models }\end{array}$ & Ordered probit. \\
\hline Findings & $\begin{array}{l}\text { Children's health is } \\
\text { positively related to } \\
\text { family income at every } \\
\text { age, and the slope of } \\
\text { the gradient increases } \\
\text { for older children }\end{array}$ & $\begin{array}{l}\text { Depsite the universal } \\
\text { health coverage, there } \\
\text { exists an income } \\
\text { gradient of children's } \\
\text { health that steepens } \\
\text { during childhood. The } \\
\text { gradient is likely due } \\
\text { to higher rate of health } \\
\text { shocks among low- } \\
\text { income children. }\end{array}$ & $\begin{array}{l}\text { In U.S., children in low } \\
\text { income families are } \\
\text { more likely than } \\
\text { children in high } \\
\text { income families to still } \\
\text { suffer from chronic } \\
\text { conditions present } 5 \\
\text { years ago. Income } \\
\text { gradient becomes } \\
\text { steeper with age, partly } \\
\text { because low income } \\
\text { children are less able } \\
\text { to recover from health } \\
\text { shocks. }\end{array}$ & $\begin{array}{l}\text { Although family } \\
\text { income has a positive } \\
\text { relationship with } \\
\text { general health status, } \\
\text { strength of the } \\
\text { relationship is smaller } \\
\text { than in US. Gradient } \\
\text { does not increase with } \\
\text { children's age. No } \\
\text { evidence of a } \\
\text { significant income } \\
\text { differential in } \\
\text { porbability of a child } \\
\text { having a chronic health } \\
\text { condition. }\end{array}$ & $\begin{array}{l}\text { More generous } \\
\text { insurance coverage at } \\
\text { early childhood is } \\
\text { associated with better } \\
\text { health at older ages } \\
\text { (ages 9-17). In } \\
\text { addition, the } \\
\text { relationship between } \\
\text { family income and } \\
\text { children's health has } \\
\text { weakened for older } \\
\text { children after the year } \\
\text { the SCHIP initiated. }\end{array}$ & $\begin{array}{l}\text { Replicate Case (2002) } \\
\text { pattern though } \\
\text { somewhat weaker. } \\
\text { Increased persistence } \\
\text { of health status among } \\
\text { older children; stronger } \\
\text { contemporaneous } \\
\text { influence of income on } \\
\text { adolescents. }\end{array}$ & $\begin{array}{l}\text { Similar findings as US } \\
\text { studies in that children } \\
\text { from higher income } \\
\text { families have better } \\
\text { health but gradient } \\
\text { flatter. No evidence of } \\
\text { more health shocks or } \\
\text { failure to respond to } \\
\text { shocks by income. } \\
\text { Some suggestion that } \\
\text { health of mother part } \\
\text { of explanation of the } \\
\text { gradient. }\end{array}$ & $\begin{array}{l}\text { Larger but flatter } \\
\text { income gradient for } \\
\text { subjective health. No } \\
\text { evidence of a } \\
\text { significant income } \\
\text { differential in } \\
\text { probablility of child } \\
\text { having a chronic health } \\
\text { condition but severity } \\
\text { is less among higher } \\
\text { income children. }\end{array}$ \\
\hline Implications & $\begin{array}{l}\text { Low family income on } \\
\text { chilren's health tend to } \\
\text { accumulate during } \\
\text { childhood. Thus, } \\
\text { children from lower } \\
\text { income families may } \\
\text { suffer from both lower } \\
\text { SES and poorer health } \\
\text { when they transition } \\
\text { into adulthood }\end{array}$ & $\begin{array}{l}\text { Policies that focus only } \\
\text { on reducing gaps in } \\
\text { access to medical care } \\
\text { may not be sufficient } \\
\text { to reduce disparities in } \\
\text { health. }\end{array}$ & $\begin{array}{l}\text { Public policies that } \\
\text { increase access to } \\
\text { medical care for low } \\
\text { income children could } \\
\text { be useful in reducing } \\
\text { the income gradient of } \\
\text { children's health. }\end{array}$ & $\begin{array}{l}\text { Family income may } \\
\text { not be a major } \\
\text { determinant of } \\
\text { children's health in } \\
\text { England. NHS may } \\
\text { infuence. Challenged } \\
\text { by Case, Lee, and } \\
\text { Paxson that findings } \\
\text { reflect miscoding of } \\
\text { chronic conditions. }\end{array}$ & $\begin{array}{l}\text { Assuring access to } \\
\text { health care in early } \\
\text { childhood may prevent } \\
\text { the income gradient of } \\
\text { children's health from } \\
\text { becoming steeper over } \\
\text { time. }\end{array}$ & $\begin{array}{l}\text { Since influence of SES } \\
\text { cumulative, } \\
\text { interventions at an } \\
\text { earlier age may be } \\
\text { most effective. }\end{array}$ & $\begin{array}{l}\text { National health service } \\
\text { can reduce gradient but } \\
\text { not come close to } \\
\text { eliminating it. }\end{array}$ & $\begin{array}{l}\text { Low income creates a } \\
\text { severeity effect among } \\
\text { children but not an } \\
\text { increase in the } \\
\text { probability of health } \\
\text { problems. }\end{array}$ \\
\hline
\end{tabular}


Table 2: A Comparison of Results from Studies of Four Countries of the Tie between Family Income and Child Health Parent's reports of child general health, 1=excellent, $\mathbf{5}=$ poor. Ordered probits

\begin{tabular}{lcllll}
\hline & & \multicolumn{4}{c}{ Age of Child } \\
\cline { 3 - 6 } Study & Country & $0-3$ & $4-8$ & $9-12$ & $13+$ \\
\hline CLP & USA & -0.183 & -0.244 & -0.268 & -0.323 \\
& & {$[0.008]$} & {$[0.008]$} & {$[0.009]$} & {$[0.008]$} \\
CS & Canada & -0.151 & -0.216 & -0.252 & -0.272 \\
& & {$[0.026]$} & {$[0.019]$} & {$[0.024]$} & {$[0.040]$} \\
CLP07 & UK & -0.143 & -0.212 & -0.203 & -0.194 \\
& & {$[0.036]$} & {$[0.026]$} & {$[0.030]$} & {$[0.034]$} \\
KNC & AU & -0.05 & -0.131 & & \\
& & {$[0.024]$} & {$[0.024]$} & & \\
M & USA & -0.079 & -0.134 & -0.132 & -0.195 \\
& & {$[0.023]$} & {$[0.018]$} & {$[0.022]$} & {$[0.036]$} \\
RJ & Germany & -0.268 & -0.277 & -0.250 & -3.52 \\
& & {$[0.050]$} & {$[0.040]$} & {$[0.043]$} & {$[0.040]$} \\
\hline
\end{tabular}

Notes: CLP $=$ Case. Lubotsky and Paxson 2002 using NHIS; CS = Currie and Stabile, 2003 using NLSCY.

CLP07=Case, Lee and Paxson 2007 using HSE and KNC= Khanam, Ngheim and Connelly 2009 using LSAC.

$\mathrm{M}=$ Murasko 2008 using MEPS. Control variables include age dummies, sex, race, parent education, $\ln$ family size with some additions that vary by study.

$\mathrm{RJ}=$ Reinhold and Jurges 2011 using data for 2003-2006 KiGGS 
Table 3: Descriptive Characteristics of ECLS-K Sample

\begin{tabular}{|c|c|c|c|c|c|c|}
\hline \multirow[b]{2}{*}{ Variable } & \multicolumn{3}{|c|}{ Kindergarten } & \multicolumn{3}{|c|}{ 8th Grade } \\
\hline & Obs & Mean & Std. & Obs & Mean & Std. \\
\hline Poor Health & 7,431 & 0.17 & 0.37 & 6,953 & 0.15 & 0.36 \\
\hline $\begin{array}{l}\text { Child Health Status }(5=\text { excellent, } \\
1=\text { poor })\end{array}$ & 7,431 & 4.33 & 0.83 & 6,953 & 4.33 & 0.81 \\
\hline Child Health Status $=$ Excellent & 7,431 & 0.53 & & 6,953 & 0.51 & \\
\hline Child Health Status $=$ Very Good & 7,431 & 0.30 & & 6,953 & 0.34 & \\
\hline Child Health Status $=$ Good & 7,431 & 0.14 & & 6,953 & 0.12 & \\
\hline Child Health Status $=$ Fair & 7,431 & 0.03 & & 6,953 & 0.03 & \\
\hline Child Health Status $=$ Poor & 7,431 & 0.00 & & 6,953 & 0.00 & \\
\hline Log Income & 7,405 & 10.51 & 0.96 & 6,953 & 10.84 & 0.85 \\
\hline Current Income (10000s) & 7,431 & 5.17 & 5.15 & 6,953 & 6.98 & 5.18 \\
\hline $\begin{array}{l}\text { Permanent Income (current and } \\
\text { previous wave) }(10000 \mathrm{~s})\end{array}$ & 7,431 & 5.17 & 5.15 & 6,953 & 6.09 & 4.46 \\
\hline School average income (10000s) & 7,032 & 5.71 & 3.31 & 6,369 & 6.02 & 2.66 \\
\hline $\begin{array}{l}\text { Parent Health }(1=\text { excellent, } \\
5=\text { poor })\end{array}$ & 7,411 & 2.26 & 0.79 & 6,933 & 2.26 & 0.79 \\
\hline $\begin{array}{l}\text { Mom Depressed }(1=\text { never, } \\
4=\text { most of the time })\end{array}$ & 7,395 & 1.34 & 0.50 & 6,928 & 1.35 & 0.51 \\
\hline Birth weight (lbs) & 7,291 & 7.38 & 1.32 & & & \\
\hline Male & 7,431 & 0.52 & 0.50 & 6,953 & 0.51 & 0.50 \\
\hline Age & 7,426 & 6.23 & 0.38 & 6,948 & 14.45 & 0.49 \\
\hline Black & 7,431 & 0.17 & 0.37 & 6,953 & 0.16 & 0.36 \\
\hline Hispanic & 7,431 & 0.17 & 0.38 & 6,953 & 0.18 & 0.38 \\
\hline Other Race & 7,431 & 0.04 & 0.20 & 6,953 & 0.04 & 0.20 \\
\hline Mom Education & 7,431 & 13.48 & 2.45 & 6,953 & 13.50 & 2.46 \\
\hline Mom Age (wave 1) & 7,431 & 33.56 & 6.49 & 6,953 & 33.82 & 6.28 \\
\hline Married & 7,431 & 0.71 & 0.45 & 6,953 & 0.70 & 0.46 \\
\hline
\end{tabular}


Table 4: Comparing Alternative Measures of Permanent Income

\begin{tabular}{|lclllll|}
\hline Grade & $\mathrm{K}$ & & 1 & 3 & 5 & 8 \\
\hline Set uses only current and prior family incomes & & & \\
Log (Perm Income) & $0.142 * * *$ & $0.165 * * *$ & $0.204 * * *$ & $0.238^{* * *}$ & $0.305^{* * *}$ \\
& $(0.037)$ & $(0.046)$ & $(0.047)$ & $(0.046)$ & $(0.055)$ \\
Set uses all years of income & & & & & \\
Log (All Years Income) & $0.248 * * *$ & $0.264 * * *$ & $0.280 * * *$ & $0.261 * * *$ & $0.305 * * *$ \\
& $(0.050)$ & $(0.054)$ & $(0.053)$ & $(0.047)$ & $(0.055)$ \\
& & & & & \\
Log (2 Year Rolling) & $0.182 * * *$ & $0.171 * * *$ & $0.254 * * *$ & $0.248 * * *$ & $0.262 * * *$ \\
& $(0.044)$ & $(0.046)$ & $(0.046)$ & $(0.041)$ & $(0.048)$ \\
& & & & & \\
Log (3 Year Rolling) & $0.182 * * *$ & $0.183 * * *$ & $0.260 * * *$ & $0.233 * * *$ & $0.261 * * *$ \\
& $(0.046)$ & $(0.048)$ & $(0.051)$ & $(0.043)$ & $(0.049)$ \\
& & & & & \\
\hline
\end{tabular}

Notes: each coefficient is from a separate regression. Standard errors in parenthesis, ${ }^{* * *} 1 \%$, $* * 5 \%, * 10 \%$ 
Table 5: The Effects of Family Income on Child Health Varying the Baseline Income Measure and Examining Future Health Outcomes

\begin{tabular}{|lccccc|}
\hline Outcome & SRHS & SRHS & SRHS & \multicolumn{1}{l|}{ SRHS } & \multicolumn{1}{l|}{ SRHS } \\
\hline Grade & $\mathrm{K}$ & 1 & 3 & 5 & 8 \\
Log (Perm Income) & $0.141^{* * *}$ & $0.165^{* * *}$ & $0.204^{* * *}$ & $0.238^{* * *}$ & $0.305^{* * *}$ \\
& $(0.037)$ & $(0.046)$ & $(0.047)$ & $(0.046)$ & $(0.055)$ \\
Log (K Income) & $0.141^{* * *}$ & $0.114^{* * *}$ & $0.088^{* *}$ & $0.113^{* * *}$ & $0.132^{* * *}$ \\
& $(0.037)$ & $(0.038)$ & $(0.036)$ & $(0.034)$ & $(0.042)$ \\
Log (1st Grade Income) & & $0.157^{* * *}$ & $0.174^{* * *}$ & $0.133^{* * *}$ & $0.175^{* * *}$ \\
& & $(0.045)$ & $(0.048)$ & $(0.040)$ & $(0.046)$ \\
Log (3rd Grade Income) & & & $0.201^{* * *}$ & $0.132^{* * *}$ & $0.191^{* * *}$ \\
& & & $(0.044)$ & $(0.040)$ & $(0.042)$ \\
Log (5th Grade Income) & & & & $0.224^{* * *}$ & $0.202^{* * *}$ \\
& & & & $(0.038)$ & $(0.045)$ \\
Observations & 7,265 & 7,001 & 6,800 & 7,032 & 6,533 \\
& & & & & \\
\hline
\end{tabular}

Note: Same controls as previous tables. Each cell is a separate regression.

Standard errors in parenthesis, $* * * 1 \%, * * 5 \%, * 10 \%$ 
Table 6a: The Effects on Family Income on Child Health Declines

\begin{tabular}{|lcccc|}
\hline Outcome & Decline in Health & Decline in Health & Decline in Health & Decline in Health \\
Grade & 1 & 3 & 5 & 8 \\
\hline & & & & \\
Log Permanent Income & $-0.039^{* *}$ & $-0.042^{* *}$ & $-0.046^{* *}$ & $-0.066^{* * *}$ \\
& $(0.019)$ & $(0.018)$ & $(0.020)$ & $(0.021)$ \\
Log Current Income & $-0.033^{*}$ & $-0.044^{* *}$ & $-0.054^{* * *}$ & $-0.041^{* *}$ \\
& $(0.017)$ & $(0.017)$ & $(0.018)$ & $(0.019)$ \\
Observations & 5,990 & 5,975 & 6,127 & 5,507 \\
R-squared & 0.040 & 0.047 & 0.124 & 0.048 \\
\hline
\end{tabular}

Note: Same controls as previous tables. Each cell is a separate regression.

Standard errors in parenthesis, ***1\%,**5\%, *10\% 
Table 6b: Comparison of Income Gradient for Children by Initial health defined according to health in Kindergarten

\begin{tabular}{|lcccc|}
\hline Outcome & SRHS & SRHS & SRHS & SRHS \\
Grade & 1 & 3 & 5 & 8 \\
Full Sample & $0.157^{* * *}$ & $0.201^{* * *}$ & $0.224^{* * *}$ & $0.239^{* * *}$ \\
& $(0.045)$ & $(0.044)$ & $(0.038)$ & $(0.045)$ \\
Observations & 6,559 & 6,247 & 7,032 & 6,533 \\
Baseline Poor Health & 0.125 & 0.031 & $0.156^{* *}$ & $0.276^{* * *}$ \\
& $(0.106)$ & $(0.075)$ & $(0.075)$ & $(0.098)$ \\
Observations & 951 & 905 & 1,044 & 979 \\
Baseline Very Good & & & & \\
Health & $0.113 * *$ & $0.224 * * *$ & $0.209 * * *$ & $0.217 * * *$ \\
& $(0.044)$ & $(0.049)$ & $(0.041)$ & $(0.047)$ \\
Observations & 5,950 & 5,668 & 6,450 & 5,968 \\
\hline
\end{tabular}

Standard errors in parenthesis, $* * * 1 \%, * * 5 \%, * 10 \%$. Other variables in regressions include male, age, race dummies, mom and dad education, mom age, parent's married. Income variable is log of current income. Baseline poor health refers to those with general health reported as poor, fair or good in kindergarten; baseline very good health refers to those reported in very good or excellent health in kindergarten. 
Table 7: Adding School Average Income to Model with and without family income

\section{Grade}

Estimates with only the noted

measure of income included

Log (Perm Income)

Log (School Mean)

Log (School Median)

Estimates with both family and

school income included

Log (Perm Income)

Log (School Mean)

Log (Perm Income)

Log (School Median)

Log (School Mean)
$\mathrm{K}$

$\begin{array}{lllll}0.142 * * * & 0.165 * * * & 0.204 * * * & 0.238 * * * & 0.305 * * * \\ (0.037) & (0.046) & (0.047) & (0.046) & (0.055)\end{array}$

$0.161 * * * \quad 0.265^{* * *}$

$0.157 * * * \quad 0.135 * *$

$0.102 *$

$(0.060)$

(0.059)

$(0.061) \quad(0.054)$

(0.056)

$0.191 * * * \quad 0.1$

(0.057)

$0.197 * * *$

$0.149 * * *$

$0.147 * * * \quad 0.092 *$

(0.052)

(0.054)

(0.045)

(0.053)

\section{8}

$\begin{array}{ll}0.124 * * * & 0.117 * * * \\ (0.039) & (0.044)\end{array}$

$0.233 * * *$

$0.259 * * *$

$(0.054) \quad(0.051)$

$0.325 * * *$

$0.108 *$

$0.215 * * * \quad 0.059$

0.058

(0.058)

(0.062)

$(0.061)$

(0.065)

(0.056)

0.048

$(0.058)$

$0.112 * * * \quad 0.124 * *$

$0.246 * * *$

$0.208^{* * *}$

$0.306^{* * * *}$

(0.038)

(0.053)

(0.058)

$(0.051)$

(0.060)

$0.134 * * \quad 0.130 * *$

0.010

0.054

$-0.005$

(0.060)

(0.062)

$(0.050)$

(0.058)

Notes: each coefficient is from a separate regression in the top rows. Sets of two coefficients from separate regressions in the bottom rows. Standard errors in parenthesis, $* * * 1 \%, * * 5 \%, * 10 \%$ 
Table 8: Effects of Family Income and School-Level Health on Child Health

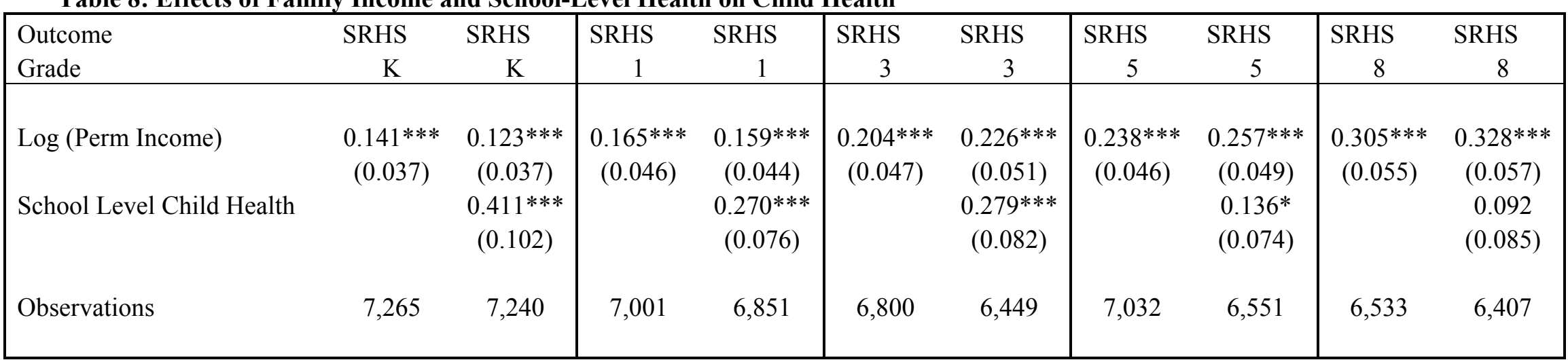

Note: Same controls as previous tables. Standard errors in parenthesis, $* * * 1 \%, * * 5 \%, * 10 \%$ 
Table 9: Marginal Effects of Permanent Income on Child Health:

Panel A: Results using Current and Prior Values of Income.

\begin{tabular}{|lccccccc|}
\hline & & Mfx & Mfx & Mfx & Mfx & Mfx & Sample \\
& & Poor & Fair & Good & Very Good & Excellent & \\
Kindergarten & $0.142^{* * *}$ & $-0.001^{*}$ & $-0.008^{* * *}$ & $-0.025^{* * *}$ & $-0.023^{* * *}$ & $0.057^{* * *}$ & 7265 \\
& $(0.037)$ & $(0.000)$ & $(0.002)$ & $(0.007)$ & $(0.006)$ & $(0.015)$ & \\
1st Grade & $0.165^{* * *}$ & $-0.001 * *$ & $-0.007 * * *$ & $-0.026^{* * *}$ & $-0.031^{* * *}$ & $0.065^{* * *}$ & 7001 \\
& $(0.046)$ & $(0.001)$ & $(0.002)$ & $(0.007)$ & $(0.009)$ & $(0.018)$ & \\
3rd Grade & $0.204^{* * *}$ & $-0.001 *$ & $-0.010^{* * *}$ & $-0.036^{* * *}$ & $-0.033^{* * *}$ & $0.081^{* * *}$ & 6800 \\
& $(0.047)$ & $(0.000)$ & $(0.003)$ & $(0.009)$ & $(0.008)$ & $(0.019)$ & \\
5th Grade & $0.238^{* * *}$ & $-0.001 * *$ & $-0.011^{* * *}$ & $-0.049 * * *$ & $-0.034^{* * *}$ & $0.095^{* * *}$ & 7032 \\
& $(0.046)$ & $(0.001)$ & $(0.002)$ & $(0.010)$ & $(0.007)$ & $(0.018)$ & \\
8th Grade & $0.305^{* * *}$ & -0.001 & $-0.014 * * *$ & $-0.049 * * *$ & $-0.057 * * *$ & $0.121^{* * *}$ & 6533 \\
& $(0.055)$ & $(0.001)$ & $(0.003)$ & $(0.010)$ & $(0.010)$ & $(0.022)$ & \\
\hline
\end{tabular}


Table 9

Panel B: Results Stratified by Baseline Health

Baseline Poor/Fair/Good Health

\begin{tabular}{|c|c|c|c|c|c|c|c|}
\hline $1 \mathrm{st}$ & Coefficient & $\begin{array}{c}\text { Mfx } \\
\text { Poor } \\
\text { Health }\end{array}$ & $\begin{array}{c}\text { Mfx } \\
\text { Fair } \\
\text { Health }\end{array}$ & $\begin{array}{c}\text { Mfx } \\
\text { Good } \\
\text { Health }\end{array}$ & $\begin{array}{c}\text { Mfx } \\
\text { Very Good } \\
\text { Health }\end{array}$ & $\begin{array}{c}\text { Mfx } \\
\text { Excellent } \\
\text { Health }\end{array}$ & Sample \\
\hline Grade & $\begin{array}{c}0.125 \\
(0.106)\end{array}$ & $\begin{array}{l}-0.005 \\
(0.004)\end{array}$ & $\begin{array}{c}-0.019 \\
(0.017)\end{array}$ & $\begin{array}{c}-0.025 \\
(0.021)\end{array}$ & $\begin{array}{c}0.017 \\
(0.015)\end{array}$ & $\begin{array}{c}0.031 \\
(0.027)\end{array}$ & 951 \\
\hline $\begin{array}{l}\text { 3rd } \\
\text { Grade }\end{array}$ & $\begin{array}{c}0.031 \\
(0.075)\end{array}$ & $\begin{array}{l}-0.000 \\
(0.001)\end{array}$ & $\begin{array}{l}-0.005 \\
(0.011)\end{array}$ & $\begin{array}{c}-0.007 \\
(0.018)\end{array}$ & $\begin{array}{c}0.002 \\
(0.005)\end{array}$ & $\begin{array}{c}0.010 \\
(0.024)\end{array}$ & 905 \\
\hline $\begin{array}{l}\text { 5th } \\
\text { Grade }\end{array}$ & $\begin{array}{c}0.156 * * \\
(0.075)\end{array}$ & $\begin{array}{l}-0.003 \\
(0.002)\end{array}$ & $\begin{array}{l}-0.019 * \\
(0.010)\end{array}$ & $\begin{array}{c}-0.038 * * \\
(0.019)\end{array}$ & $\begin{array}{c}0.011 * \\
(0.006)\end{array}$ & $\begin{array}{c}0.050 * * \\
(0.024)\end{array}$ & 1,044 \\
\hline $\begin{array}{l}\text { 8th } \\
\text { Grade }\end{array}$ & $\begin{array}{c}0.276^{* * *} \\
(0.098)\end{array}$ & $\begin{array}{l}-0.003 \\
(0.003) \\
\end{array}$ & $\begin{array}{c}-0.026 * * \\
(0.012) \\
\end{array}$ & $\begin{array}{c}-0.067 * * * \\
(0.025)\end{array}$ & $\begin{array}{c}0.011 \\
(0.008) \\
\end{array}$ & $\begin{array}{c}0.086 * * * \\
(0.030)\end{array}$ & 979 \\
\hline
\end{tabular}

Baseline Very Good/Excellent Health

\begin{tabular}{|c|c|c|c|c|c|c|c|}
\hline & Coefficient & $\begin{array}{c}\text { Mfx } \\
\text { Poor } \\
\text { Health }\end{array}$ & $\begin{array}{c}\text { Mfx } \\
\text { Fair } \\
\text { Health }\end{array}$ & $\begin{array}{c}\text { Mfx } \\
\text { Good } \\
\text { Health }\end{array}$ & $\begin{array}{c}\text { Mfx } \\
\text { Very Good } \\
\text { Health }\end{array}$ & $\begin{array}{c}\text { Mfx } \\
\text { Excellent } \\
\text { Health }\end{array}$ & Sample \\
\hline $\begin{array}{l}\text { 1st } \\
\text { Grade }\end{array}$ & $\begin{array}{c}0.113 * * \\
(0.044)\end{array}$ & $\begin{array}{l}-0.000 \\
(0.000)\end{array}$ & $\begin{array}{c}-0.003 * * \\
(0.001)\end{array}$ & $\begin{array}{c}-0.014 * * * \\
(0.006)\end{array}$ & $\begin{array}{c}-0.026^{* *} \\
(0.010)\end{array}$ & $\begin{array}{c}0.043 * * \\
(0.017)\end{array}$ & 5,950 \\
\hline $\begin{array}{l}3 \text { rd } \\
\text { Grade }\end{array}$ & $\begin{array}{c}0.224 * * * \\
(0.049)\end{array}$ & $\begin{array}{l}-0.000 * \\
(0.000)\end{array}$ & $\begin{array}{c}-0.007 * * * \\
(0.002)\end{array}$ & $\begin{array}{c}-0.033 * * * \\
(0.007)\end{array}$ & $\begin{array}{c}-0.046^{* * *} \\
(0.010)\end{array}$ & $\begin{array}{c}0.087 * * * \\
(0.019)\end{array}$ & 5,668 \\
\hline $\begin{array}{l}\text { 5th } \\
\text { Grade }\end{array}$ & $\begin{array}{c}0.209 * * * \\
(0.041)\end{array}$ & $\begin{array}{l}-0.001 \\
(0.000)\end{array}$ & $\begin{array}{c}-0.006^{* * *} \\
(0.002)\end{array}$ & $\begin{array}{c}-0.040 * * * \\
(0.008)\end{array}$ & $\begin{array}{c}-0.036 * * * \\
(0.007)\end{array}$ & $\begin{array}{c}0.083 * * * \\
(0.016)\end{array}$ & 6,450 \\
\hline $\begin{array}{l}\text { 8th } \\
\text { Grade }\end{array}$ & $\begin{array}{c}0.217 * * * \\
(0.047)\end{array}$ & $\begin{array}{c}-0.000^{*} \\
(0.000)\end{array}$ & $\begin{array}{c}-0.009 * * * \\
(0.002)\end{array}$ & $\begin{array}{c}-0.032 * * * \\
(0.007)\end{array}$ & $\begin{array}{c}-0.045^{* * *} \\
(0.010)\end{array}$ & $\begin{array}{c}0.085 * * * \\
(0.018)\end{array}$ & 5,968 \\
\hline
\end{tabular}

Standard errors in parenthesis, $* * * 1 \%, * * 5 \%, * 10 \%$ 


\section{Figures}

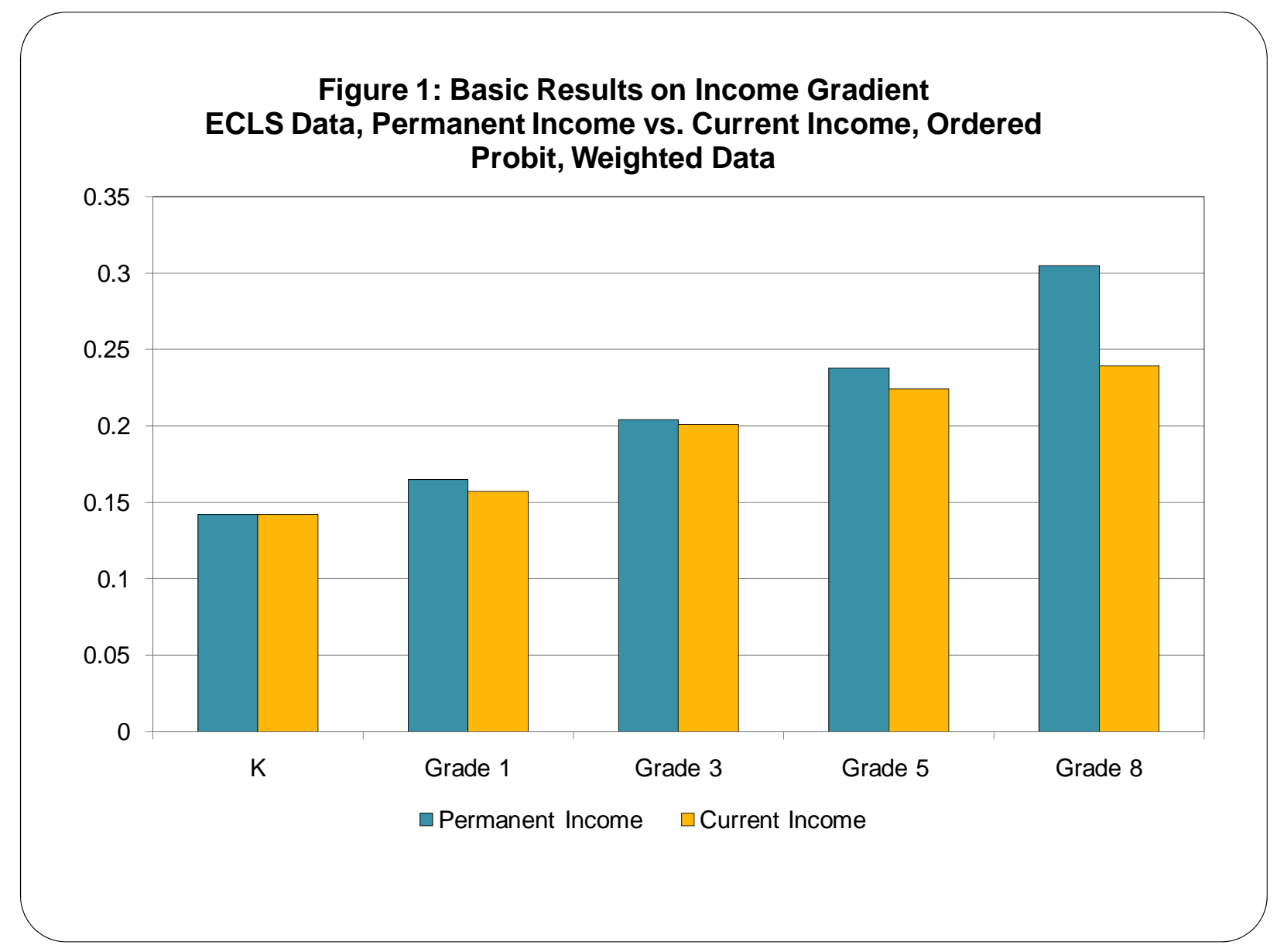


Figure 2

Comparison of Estimates by Income Measure

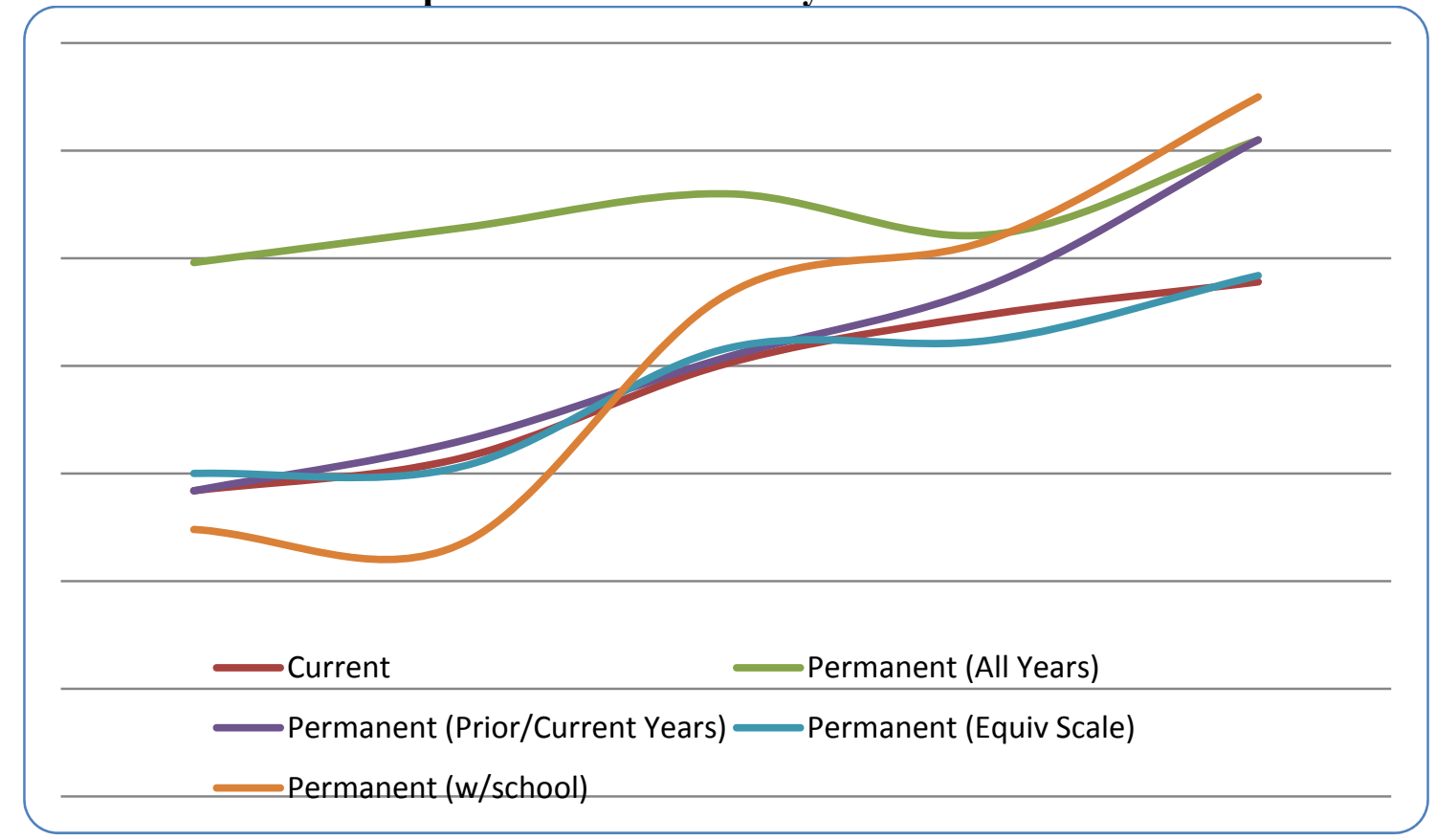

Notes: All estimates include birth weight 


\section{Appendix Tables}

\section{Tables}

\begin{tabular}{lcc}
\multicolumn{3}{c}{ Appendix Table 1: Health of Poor vs. Nonpoor Children; NHIS Data, Children 2-17 US 2001-05 } \\
\hline Health Measure & Poor & Nonpoor \\
\hline Low birth weight & 0.112 & 0.078 \\
Ever told had asthma & .159 & .131 \\
Ever mental problems & .119 & .079 \\
Ever told ADHD & .071 & .060 \\
Activity limitations & .114 & .070 \\
ages 2-3 & .061 & .037 \\
ages 4-8 & .097 & .062 \\
ages 9-12 & .139 & .067 \\
Days missed Illness/injury 12 mos & 4.471 & 3.531 \\
Any chronic condition & .324 & .265 \\
$\mathrm{~N}$ & 7,363 & 36,858 \\
\hline
\end{tabular}

Source: Currie and Lin 2007. 


\begin{tabular}{|c|c|c|c|c|c|}
\hline Outcome & SRHS & SRHS & SRHS & SRHS & SRHS \\
\hline Grade & K & 1 & 3 & 5 & 8 \\
\hline Log (Current Income) & $\begin{array}{c}0.142 * * * \\
(0.037)\end{array}$ & $\begin{array}{c}0.157^{* * *} \\
(0.045)\end{array}$ & $\begin{array}{c}0.201 * * * \\
(0.044)\end{array}$ & $\begin{array}{c}0.224^{* * *} \\
(0.038)\end{array}$ & $\begin{array}{c}0.239 * * * \\
(0.045)\end{array}$ \\
\hline Male & $\begin{array}{c}-0.113 * * \\
(0.049)\end{array}$ & $\begin{array}{c}0.011 \\
(0.055)\end{array}$ & $\begin{array}{l}-0.000 \\
(0.057)\end{array}$ & $\begin{array}{l}-0.073 \\
(0.046)\end{array}$ & $\begin{array}{c}-0.086 \\
(0.054)\end{array}$ \\
\hline Age & $\begin{array}{l}-0.119 \\
(0.076)\end{array}$ & $\begin{array}{c}-0.055 \\
(0.077)\end{array}$ & $\begin{array}{l}-0.101 \\
(0.073)\end{array}$ & $\begin{array}{c}-0.083 \\
(0.096)\end{array}$ & $\begin{array}{c}-0.141 * * \\
(0.061)\end{array}$ \\
\hline Black & $\begin{array}{l}-0.041 \\
(0.100)\end{array}$ & $\begin{array}{c}-0.204^{* *} \\
(0.102)\end{array}$ & $\begin{array}{l}-0.121 \\
(0.096)\end{array}$ & $\begin{array}{c}-0.241^{* *} \\
(0.097)\end{array}$ & $\begin{array}{c}-0.247^{* * *} \\
(0.088)\end{array}$ \\
\hline Hispanic & $\begin{array}{l}-0.082 \\
(0.060)\end{array}$ & $\begin{array}{c}-0.174^{* * *} \\
(0.063)\end{array}$ & $\begin{array}{l}-0.057 \\
(0.065)\end{array}$ & $\begin{array}{c}-0.203^{* * *} \\
(0.061)\end{array}$ & $\begin{array}{c}-0.231 * * * \\
(0.067)\end{array}$ \\
\hline Other Race & $\begin{array}{l}-0.088 \\
(0.107)\end{array}$ & $\begin{array}{l}-0.092 \\
(0.135)\end{array}$ & $\begin{array}{c}0.155 \\
(0.113)\end{array}$ & $\begin{array}{l}-0.143 \\
(0.108)\end{array}$ & $\begin{array}{c}0.018 \\
(0.128)\end{array}$ \\
\hline Birth Weight & $\begin{array}{c}0.022 \\
(0.019)\end{array}$ & $\begin{array}{c}0.014 \\
(0.022)\end{array}$ & $\begin{array}{c}0.028 \\
(0.022)\end{array}$ & $\begin{array}{c}0.018 \\
(0.019)\end{array}$ & $\begin{array}{c}0.005 \\
(0.019)\end{array}$ \\
\hline Maternal Education & $\begin{array}{c}0.054^{* * *} \\
(0.012)\end{array}$ & $\begin{array}{c}0.040 * * * \\
(0.015)\end{array}$ & $\begin{array}{c}0.058 * * * \\
(0.014)\end{array}$ & $\begin{array}{c}0.051^{* * *} \\
(0.013)\end{array}$ & $\begin{array}{c}0.044 * * * \\
(0.014)\end{array}$ \\
\hline Paternal Education & $\begin{array}{c}0.016 \\
(0.012)\end{array}$ & $\begin{array}{l}0.026^{*} \\
(0.014)\end{array}$ & $\begin{array}{c}0.005 \\
(0.015)\end{array}$ & $\begin{array}{l}0.022^{*} \\
(0.012)\end{array}$ & $\begin{array}{c}0.000 \\
(0.012)\end{array}$ \\
\hline Maternal Age & $\begin{array}{c}0.004 \\
(0.004)\end{array}$ & $\begin{array}{c}-0.007 * \\
(0.004)\end{array}$ & $\begin{array}{l}-0.002 \\
(0.005)\end{array}$ & $\begin{array}{l}-0.001 \\
(0.004)\end{array}$ & $\begin{array}{l}-0.004 \\
(0.004)\end{array}$ \\
\hline Parents Married & $\begin{array}{c}0.218^{* *} \\
(0.087)\end{array}$ & $\begin{array}{c}0.186 * * \\
(0.086)\end{array}$ & $\begin{array}{c}-0.122 \\
(0.088)\end{array}$ & $\begin{array}{l}-0.106 \\
(0.069)\end{array}$ & $\begin{array}{c}-0.077 \\
(0.067)\end{array}$ \\
\hline Missing Parent Information & $\begin{array}{c}0.242 * * \\
(0.095)\end{array}$ & $\begin{array}{c}0.218 * * \\
(0.093)\end{array}$ & $\begin{array}{c}0.063 \\
(0.098)\end{array}$ & $\begin{array}{l}-0.025 \\
(0.079)\end{array}$ & $\begin{array}{c}0.156^{* *} \\
(0.077)\end{array}$ \\
\hline Observations & 7265 & 6559 & 6247 & 7032 & 6533 \\
\hline
\end{tabular}

Standard errors in parenthesis, $* * * 1 \%, * * 5 \%, * 10 \%$ 
Appendix Table 3: Comparing Income and alternative equivalent scales

\begin{tabular}{|llllll|}
\hline Grade & $\mathrm{K}$ & 1 & 3 & 5 & 8 \\
\hline Log (Perm Income) & $0.142^{* * *}$ & $0.165^{* * *}$ & $0.204^{* * *}$ & $0.238^{* * *}$ & $0.305^{* * *}$ \\
& $(0.037)$ & $(0.046)$ & $(0.047)$ & $(0.046)$ & $(0.055)$ \\
Log (Perm Income with Equiv Scale) & $0.150^{* * *}$ & $0.155^{* * *}$ & $0.205^{* * *}$ & $0.211^{* * *}$ & $0.229^{* * *}$ \\
2-parameter & $(0.037)$ & $(0.043)$ & $(0.044)$ & $(0.043)$ & $(0.049)$ \\
Log (Perm Income with Equiv Scale) & $0.150^{* * *}$ & $0.153^{* * *}$ & $0.208^{* * *}$ & $0.212^{* * *}$ & $0.242^{* * *}$ \\
3-parameter & $(0.037)$ & $(0.043)$ & $(0.044)$ & $(0.043)$ & $(0.050)$ \\
\hline
\end{tabular}

Notes: each coefficient is from a separate regression. Standard errors in parenthesis, $* * * 1 \%$, $* * 5 \%, * 10 \%$ 
Appendix Table 4: Results for Balanced and Unbalanced Samples

\begin{tabular}{|c|c|c|c|c|c|c|c|c|c|c|}
\hline Outcome & SRHS & SRHS & SRHS & SRHS & SRHS & SRHS & SRHS & SRHS & SRHS & SRHS \\
\hline \multirow[t]{2}{*}{ Grade } & K & $\mathrm{K}$ & 1 & 1 & 3 & 3 & 5 & 5 & 8 & 8 \\
\hline & Unbalanced & Balanced & Unbalanced & Balanced & Unbalanced & Balanced & Unbalanced & Balanced & Unbalanced & Balanced \\
\hline \multirow[t]{2}{*}{ Log (Perm Income) } & $0.142 * * *$ & $0.130 * * *$ & $0.165^{* * *}$ & $0.177^{* * *}$ & $0.204^{* * *}$ & $0.218^{* * *}$ & $0.238^{* * *}$ & $0.252 * * *$ & $0.305^{* * *}$ & $0.283 * * *$ \\
\hline & $(0.037)$ & $(0.044)$ & $(0.046)$ & $(0.055)$ & $(0.047)$ & $(0.055)$ & $(0.046)$ & $(0.054)$ & $(0.055)$ & $(0.058)$ \\
\hline \multirow[t]{2}{*}{ Male } & $-0.113^{* *}$ & $-0.130 * *$ & -0.000 & -0.036 & 0.006 & 0.011 & -0.072 & -0.083 & -0.082 & -0.079 \\
\hline & $(0.049)$ & $(0.055)$ & $(0.053)$ & (0.059) & $(0.053)$ & (0.059) & $(0.046)$ & $(0.051)$ & $(0.054)$ & $(0.057)$ \\
\hline \multirow[t]{2}{*}{ Age } & -0.119 & $-0.149 *$ & -0.070 & -0.066 & $-0.137 *$ & -0.097 & -0.077 & -0.105 & $-0.135^{* *}$ & $-0.136 * *$ \\
\hline & $(0.076)$ & $(0.085)$ & $(0.073)$ & $(0.081)$ & $(0.074)$ & $(0.082)$ & $(0.098)$ & $(0.116)$ & $(0.062)$ & $(0.066)$ \\
\hline \multirow[t]{2}{*}{ Black } & -0.041 & 0.008 & $-0.202 * *$ & -0.183 & $-0.212 * *$ & $-0.242 * *$ & $-0.230 * *$ & $-0.204 *$ & $-0.212 * *$ & $-0.173 *$ \\
\hline & $(0.100)$ & $(0.121)$ & $(0.097)$ & $(0.119)$ & $(0.099)$ & $(0.114)$ & $(0.098)$ & $(0.114)$ & $(0.091)$ & $(0.098)$ \\
\hline \multirow[t]{2}{*}{ Hispanic } & -0.082 & -0.090 & $-0.214^{* * *}$ & $-0.265 * * *$ & -0.090 & -0.091 & $-0.192 * * *$ & $-0.174 * *$ & $-0.212 * * *$ & $-0.204 * * *$ \\
\hline & $(0.060)$ & $(0.072)$ & $(0.061)$ & $(0.069)$ & $(0.063)$ & $(0.069)$ & $(0.061)$ & $(0.068)$ & $(0.067)$ & $(0.074)$ \\
\hline \multirow[t]{2}{*}{ Other Race } & -0.088 & -0.086 & -0.119 & -0.149 & 0.097 & 0.124 & -0.150 & -0.086 & 0.025 & -0.001 \\
\hline & $(0.107)$ & $(0.127)$ & (0.135) & $(0.155)$ & (0.108) & $(0.126)$ & (0.111) & $(0.122)$ & $(0.136)$ & $(0.147)$ \\
\hline \multirow[t]{2}{*}{ Birth Weight } & 0.022 & 0.010 & 0.018 & 0.009 & 0.030 & 0.032 & 0.016 & 0.004 & 0.004 & -0.003 \\
\hline & $(0.019)$ & $(0.022)$ & $(0.021)$ & $(0.023)$ & $(0.020)$ & $(0.022)$ & $(0.019)$ & $(0.022)$ & $(0.019)$ & $(0.020)$ \\
\hline \multirow[t]{2}{*}{ Maternal Education } & $0.054 * * *$ & $0.043 * * *$ & $0.043 * * *$ & $0.041 * * *$ & $0.056 * * *$ & $0.057 * * *$ & $0.050 * * *$ & $0.052 * * *$ & $0.038 * * *$ & $0.045^{* * *}$ \\
\hline & $(0.012)$ & $(0.014)$ & $(0.014)$ & $(0.015)$ & $(0.013)$ & $(0.014)$ & $(0.013)$ & $(0.014)$ & $(0.014)$ & $(0.014)$ \\
\hline \multirow[t]{2}{*}{ Paternal Education } & 0.016 & $0.024^{*}$ & 0.017 & 0.010 & 0.004 & 0.000 & $0.022^{*}$ & 0.019 & -0.006 & -0.009 \\
\hline & $(0.012)$ & $(0.014)$ & $(0.015)$ & $(0.016)$ & $(0.014)$ & $(0.015)$ & $(0.012)$ & $(0.013)$ & $(0.013)$ & $(0.013)$ \\
\hline \multirow[t]{2}{*}{ Maternal Age } & 0.004 & 0.007 & $-0.007 * *$ & -0.006 & -0.002 & -0.001 & -0.002 & 0.000 & -0.005 & -0.005 \\
\hline & $(0.004)$ & $(0.005)$ & $(0.004)$ & $(0.004)$ & $(0.004)$ & $(0.005)$ & $(0.004)$ & $(0.005)$ & $(0.004)$ & $(0.004)$ \\
\hline \multirow[t]{2}{*}{ Parents Married } & $0.218^{* *}$ & $0.309 * * *$ & $0.164 * *$ & $0.263 * * *$ & -0.080 & -0.110 & -0.058 & -0.019 & -0.044 & -0.082 \\
\hline & $(0.087)$ & $(0.099)$ & $(0.083)$ & $(0.095)$ & $(0.081)$ & $(0.092)$ & $(0.067)$ & $(0.078)$ & $(0.066)$ & $(0.072)$ \\
\hline Observations & 7265 & 5926 & 7001 & 5926 & 6800 & 5926 & 7032 & 5926 & 6533 & 5926 \\
\hline Test of Equality & & 0.511 & & 0.597 & & 0.545 & & 0.562 & & 0.375 \\
\hline
\end{tabular}

Notes: Additional Control: Missing Parental Information. Standard errors in parenthesis, ${ }^{* * *} 1 \%, * * 5 \%, * 10 \%$ 
Appendix 2: Discussion of Motivating Model

\section{BASIC MODEL}

Underlying the research on the income gradient that focuses on children is a standard model based on work by Grossman (1972 and 2000).

The model begins with a family utility maximization problem

$$
U_{t}=U\left(H_{t}, X_{t}, C_{t}, L_{t}^{l} ; \eta_{t}^{u}, \varepsilon_{t}^{u}\right)
$$

where $U_{t}$ is utility of the family at time t, $H_{t}$ is the health of a child, $X_{t}$ is a set of goods that affects

child health (e.g., food, toys and housing), $C_{t}$ represents other commodities consumed by the household, $\left(L_{t}^{l}\right)$ is leisure time, and $\eta_{t}^{u}$ and $\varepsilon_{t}^{u}$ are exogenous observable and unobservable

factors, respectively, that influence $U_{t}$.

Following the accumulation of health stock as in Grossman, the production of child health can be represented as:

$$
H_{t}=H\left(X_{t}, L_{t}^{h} ; \eta_{t}^{h}, \varepsilon_{t}^{h}\right)
$$

where $L_{t}^{h}$ is the amount of time used in the production of child health, $\eta_{t}^{h}$ and $\varepsilon_{t}^{h}$ are respectively

exogenous observable and unobservable variables influencing $H_{t}$. (Note: $H_{t-1}$ is sometimes included in these models as well but the original Grossman model used initial health stock, which might best be captured by stock at birth and is sometimes empirically captured as birth weight.)

The budget constraint of the household or family can be represented as

$$
Y_{t}=w_{t} L_{t}^{L}=P_{t}^{X} X_{t}+P_{t}^{C} C_{t}
$$

where $Y_{t}$ is family income, $L_{t}^{L}$ is the time spent to earn wage income, $w_{t}, P_{t}^{X}$ and $P_{t}^{C}$ are respectively the wage rate, and prices of $X_{t}$ and $C_{t}$.

The household's time constraint can be thought of as 


$$
L=L_{t}^{l}+L_{t}^{L}+L_{t}^{h}
$$

where $L$ is the total fixed amount of time available (e.g., 24 hours per day).

A household maximizes its intertemporal utility with a discount rate $a$, subject to the budget and time constraints plus the condition of positive initial stock of child health ( $H_{0}>0$, frequently conceived of as birth weight).

Taking first derivatives of the Lagrangian function with respect to child health, and taking its lag repeatedly until the initial condition is met, the Marshallian demand function for child health is:

$$
H_{t}^{*}=H\left(H_{0}, \omega_{k} ; \eta_{t}^{h}, \eta_{t}^{u}, \varepsilon_{t}^{h}, \varepsilon_{t}^{u}\right)
$$

where $\omega=\left\{H, X, C, L^{L}, L^{l}, L^{H}\right\}$ and $k=1,2, \ldots, t-1$.

According to (5) the optimal level of child health is determined by allocation of parental time between income generated through work, household chores and leisure, the consumption of child healthrelated goods and other goods and services

The empirical specification is then something like the following:

$$
H_{i t}=\alpha Y+\beta Z_{i t}+\mu_{i t}
$$

where $H_{i t}$ is the stock of health of child i in period $\mathrm{t}$, , Y represents average income of the family, where there is a question of whether current or permanent income is preferred, $Z_{i t}$ is a set of exogenous variables that affect child health and $\mu_{i t}$ represents unobservable determinants of $\mathrm{H}$. Again $H_{i t-1}$, the stock of health of child $\mathrm{i}$ in period $\mathrm{t}-1$, is sometimes included to reduce unobserved influences on child health. The error term of this demand equation, $\mu_{i t}$ has two components: a child specific component that does not vary over time and a time varying component which is assumed to be exogenous and uncorrelated over time. 